\title{
Caminicella sporogenes gen. nov., sp. nov., a novel thermophilic spore-forming bacterium isolated from an East-Pacific Rise hydrothermal vent
}

1,4,5 Laboratoire de
Microbiologie et de
Biotechnologie des
Extrêmophiles,
Département de
Valorization des
Produits ${ }^{1}$, Laboratoire
de Géochimie et de
Métallogénie,
Département
Géosciences Marines ${ }^{4}$,
Laboratoire
'Biotechnologie et
Molécules Marines',
Département de
Valorization des
Produits ${ }^{5}$ IFREMER,
Centre de Brest, BP 70,
29280 Plouzané, France
2 UMR 7622, Laboratoire
de Biologie Cellulaire et
Moléculaire du
Développement, 7 quai
St Bernard, 75252 Paris
Cédex 05, France
3 Laboratoire de
Microbiologie
Industrielle, URCA, UFR
Sciences, BP 1039,
Moulin de la Housse,
51687 Reims Cedex 2,
France
6 Laboratoire
Environnement Profond,
Direction des Ressources
Océaniques, IFREMER,
Centre de Brest, BP 70,
29280 Plouzané, France

1,4,5 Laboratoire de
Microbiologie et
Biotechnologie des Biotechnologie des Produits ${ }^{1}$, Laboratoire de Géochimie et de tétallogénie Géosciences Marines ${ }^{4}$, Laboratoire Valorization des Produits $^{5}$, IFREMER Centre de Brest, BP 70, 29280 Plouzané, France Moléculaire du Développement, 7 quai St Bernard, 75252 Paris

Laboratoire de Sciences, BP 1039 Moulin de la Housse, 51687 Reims Cedex 2

Laboratoire 29280 Plouzané, France

\author{
Karine Alain, ${ }^{1}$ Patricia Pignet, ${ }^{1}$ Magali Zbinden, ${ }^{2}$ Morgane Quillevere, ${ }^{1}$ \\ Francis Duchiron, ${ }^{3}$ Jean-Pierre Donval, ${ }^{4}$ Françoise Lesongeur, ${ }^{1}$ \\ Gérard Raguenes, ${ }^{5}$ Philippe Crassous, ${ }^{6}$ Joël Querellou ${ }^{1}$ \\ and Marie-Anne Cambon-Bonavita ${ }^{1}$
}

Author for correspondence: Karine Alain. Tel: +332982245 53. Fax: +33298224757. e-mail: karine.alain@ifremer.fr
A novel thermophilic, anaerobic, strictly chemoorganoheterotrophic bacterium, designated as AM1114 ${ }^{\top}$, was isolated from a deep-sea hydrothermal vent sample from the East-Pacific Rise (EPR $13^{\circ} \mathrm{N}$ ). The cells were long (3-10 $\mu \mathrm{m})$ rods, motile with peritrichous flagella, and exhibited a Gramnegative cell wall ultrastructure. In the late stationary phase of growth, cells formed an ovoid, refractile, terminal endospore. They grew at 45-65 ${ }^{\circ} \mathrm{C}$ inclusive (optimum 55-60 ${ }^{\circ} \mathrm{C}$; doubling time approx. $45 \mathrm{~min}$ ), at pH 4.5-8.0 inclusive (optimum pH 7.5-8.0) and at sea salt concentrations of 20-60 $\mathrm{g} \mathrm{I}^{-1}$ inclusive (optimum 25-30 $\mathrm{g} \mathrm{I}^{-1}$ ). Strain AM1114' was an obligately heterotrophic bacterium able to ferment a mixture of 20 amino acids, complex proteinaceous substrates (such as yeast extract, brain-heart infusion or peptone), and carbohydrates such as glucose, galactose or maltose. The main fermentation products on glucose/yeast extract/peptone/sulfur medium were hydrogen, carbon dioxide, butyrate, ethanol, acetate, formate and L-alanine. The G+C content of the genomic DNA (determined by thermal denaturation) was 24.2 $\pm 1 \mathrm{~mol} \%$. Phylogenetic analyses of the 16S rRNA gene located the strain within cluster $\mathrm{XI}$ of the lineage encompassing the genus Clostridium and related genera (sensu Collins et al., 1994), in the bacterial domain. On the basis of 165 rDNA sequence comparisons and physiological and biochemical characteristics, it is proposed that the isolate should be described as a novel genus, namely Caminicella gen. nov., of which Caminicella sporogenes sp. nov. is the type species. The type strain is $\mathrm{AM} 114^{\mathrm{T}}\left(=\mathrm{DSM} 14501^{\mathrm{T}}=\mathrm{CIP}^{107141^{\mathrm{T}}}\right)$.

Keywords: deep-sea hydrothermal vent, thermophile, Clostridiales, Caminicella sporogenes

\section{INTRODUCTION}

Over the past decade, microbiological investigations of deep-sea hydrothermal vents from a number of geographically distant sites have revealed the presence of a

Published online ahead of print on 18 January 2002 as DOI 10.1099/ ijs.0.02142-0.

The GenBank/EMBL/DDBJ accession number for the $16 \mathrm{~S}$ rDNA sequence of strain AM1114 ${ }^{\top}$ is AJ320233. phylogenetically and physiologically diverse community of thermophilic and hyperthermophilic microorganisms thriving in the hottest part of the hydrothermal vent ecosystem. Representatives species of both the Bacteria and the Archaea have been isolated from deep-sea vents. Physiological types isolated from this biotope include chemolithoautotrophs, chemoorganoheterotrophs and mixotrophs (Jeanthon, 2000). Recently, several molecular phylogenetic approaches conducted by means of the comparison of $16 \mathrm{~S}$ rRNA gene sequences have revealed a plethora of novel 
microbial lineages previously unknown for deep-sea hydrothermal vents (Polz et al., 1995; Moyer et al., 1995, 1998; Takai et al., 1999; Reysenbach et al., 2000; Longnecker et al., 2001). In this work, we report the isolation and characterization of a strain belonging to cluster XI of the 'Clostridia and relatives' group (according to the scheme of Collins et al., 1994).

The Clostridiales constitute one of the largest of the eubacterial taxa. It encompasses a complex range of Gram-negative or Gram-positive, psychrophilic, mesophilic or thermophilic, spore-forming or non-sporeforming, chemoorganoheterotrophic or chemolithotrophic bacteria that can be found in a variety of habitats, and includes a large number of eukaryotic pathogens (Cato et al., 1986). Among this group of micro-organisms, 19 clusters have been defined by Collins et al. within the genus Clostridium and related genera, on the basis of phylogenetic 16S rDNA sequence analysis (Collins et al., 1994). However, the inability to identify clear-cut phenotypic discriminatory properties essential for circumscribing clusters defined only by phylogenetic analysis hinders the reclassification process and leads to 'artificial' clustering. Consequently, the genus Clostridium, as well as other genera placed in the Clostridium subphylum of the low-G + C Gram-positive bacteria, is always in revision in order to make the taxonomy consistent with the phylogeny (Rainey et al., 1993; Stackebrandt et al., 1999).

Members of cluster XI of the 'Clostridia and relatives' group exhibit a wide range of phenotypes (Andreesen et al., 1970; Adamse, 1980; Braun et al., 1981; Lux et al., 1992; Jalava et al., 1999; Ravot et al., 1999). Notably, this cluster comprises few extreme microorganisms such as alkaliphiles (Li et al., 1993, 1994; Collins et al., 1994; Kevbrin et al., 1998; Takai et al., 2001), moderate thermophiles (Li et al., 1993, 1994) and halophiles (Fendrich et al., 1990). Although this cluster encompasses an extremely diverse range of metabolic and physiological properties, this group is phylogenetically well defined (Collins et al., 1994).

In 1999, hydrothermal samples were collected from a deep-sea vent located on the East-Pacific Rise (EPR $13^{\circ} \mathrm{N}$ ). We describe the isolation (from one of these samples) and characterization of a thermophilic, spore-forming bacterium having phenotypic and phylogenetic characteristics consistent with its assignment to a new genus within the Clostridiales.

\section{METHODS}

Collection of samples. In 1999, a deep-sea vent field located on the East-Pacific Rise [Elsa (HOT 3) $103^{\circ} 56^{\prime} 326 \mathrm{~W}$, $\left.12^{\circ} 48^{\prime} 200 \mathrm{~N}\right]$ was explored during the 'Advanced Microbiological Studies of Thermophiles: Adaptations and Diversity' oceanographic cruise. White entire tube samples of the hydrothermal vent polychaete Alvinella pompejana, which inhabits the surface of active sulfide structures ('chimneys', 'smokers'), attached to small fragments of chimney rocks, were collected by the man-operated Nautile submersible. After collection, the samples were immediately transferred into an anaerobic chamber and then, after removal of the tubes' inner contents, placed in $50 \mathrm{ml}$ serum vials filled with a sterile solution of $3 \%$ sea salts $(\mathrm{v} / \mathrm{v})$ (Sigma). They were stored at $4{ }^{\circ} \mathrm{C}$ until enrichment in the laboratory.

Enrichment and purification procedures. Cultures were enriched and purified anaerobically in a medium containing the following (per 1): $30 \mathrm{~g}$ sea salts (Sigma), 6.05 g PIPES buffer (Sigma), 0.2 g yeast extract (Difco), 0.2 g D(+)glucose (Sigma), 0.2 g dextran (produced by Leuconostoc mesenteroides strain B-512, mol. wt 148000; Sigma), 2 g sterile $A$. pompejana pulverized tubes, $0.5 \mathrm{ml}$ vitamin mixture (Balch et al., 1979), $10 \mathrm{ml}$ trace-element solution (Balch et al., 1979) and $1 \mathrm{mg}$ resazurin (Sigma). The medium was

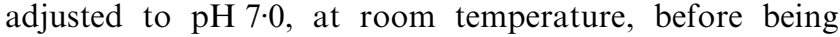
autoclaved. All manipulations preceding the enrichment and isolation experiments were performed in an anaerobic chamber, under an atmosphere of $\mathrm{N}_{2} / \mathrm{CO}_{2} / \mathrm{H}_{2}(90: 5: 5)$. The sterile medium was reduced using $0.5 \mathrm{~g} \mathrm{l}^{-1}$ sodium sulfide, then distributed into serum vials before inoculation. Enrichment cultures were performed at $60{ }^{\circ} \mathrm{C}$ without agitation by inoculating a $1 \mathrm{ml}$ sample directly into each vial filled with $25 \mathrm{ml}$ medium. After the enrichment experiments, positive cultures were subcultured and then purified by using the dilution-to-extinction technique (Baross, 1995). The purity of the strain was confirmed by microscopic observations and by cloning and sequencing of $1016 \mathrm{~S}$ rDNA clone genes.

Culture medium and conditions. The new isolate was grown on glucose/yeast extract/peptone/sulfur (GYPS) medium containing the following (per litre): $30 \mathrm{~g}$ sea salts (Sigma), 6.05 g PIPES buffer (Sigma), 0.5 g yeast extract (Difco), $1 \mathrm{~g}$ bacto-peptone (Difco), $5 \mathrm{~g} \mathrm{D}(+)$-glucose (Sigma), $12 \mathrm{~g}$ elemental sulfur (Prolabo) and $0 \cdot 1 \%(\mathrm{v} / \mathrm{v})$ resazurin solution. Its $\mathrm{pH}$ was adjusted to $7 \cdot 5$ before autoclaving, and the medium was reduced by $0.5 \mathrm{~g}$ sodium sulfide $1^{-1}$ before inoculation. Unless indicated otherwise, cultures were incubated at $60{ }^{\circ} \mathrm{C}$ under the anaerobic chamber gas mixture, at atmospheric pressure.

Observation of the culture, and quantification. Cells were observed under a light microscope (model $\mathrm{BH} 2$; Olympus) equipped with a phase-contrast oil-immersion objective ( $\times 100$ magnification). Cells were quantified by direct cell counting using a Thoma chamber (depth, 0.02 mm). Alternatively, cells were fixed with $1 \%$ glutaraldehyde $(\mathrm{v} / \mathrm{v})$ for $45 \mathrm{~min}$ at room temperature and stored at $-20{ }^{\circ} \mathrm{C}$ before being counted in a Thoma chamber.

Morphology. The cells were Gram-stained by using the Bacto 3-step Gram stain Set-S (Difco). The Gram type was determined by using the Ryu non-staining KOH test (Ryu, 1940; Buck, 1982; Powers, 1995). The SpotTest flagella stain (Difco) was used for flagella detection.

For scanning electron microscopy, cells were fixed with $10 \%$ formaldehyde $(\mathrm{v} / \mathrm{v})$ for $1 \mathrm{~h}$, displayed on filters $(0.22 \mu \mathrm{m}$ pore size; Nucleopore) and dried overnight at room temperature. Samples were then coated with gold (SCD040; Balzers) and examined with a scanning electron microscope (XL 30 LaB6; Philips).

For transmission electron microscopy, cultures were fixed at room temperature in a fixative solution containing $3 \%$ glutaraldehyde (v/v), $0 \cdot 2 \mathrm{M}$ cacodylate buffer, $\mathrm{pH} 7 \cdot 4$, and $0 \cdot 35 \mathrm{M}$ sucrose. After centrifugation at $2000 \mathrm{~g}$ for $20 \mathrm{~min}$, the fixative was carefully removed and replaced with the 
washing solution. Post-fixation in osmium tetroxide (1 vol. in 1 vol. of $0 \cdot 2 \mathrm{M}$ cacodylate buffer) was performed. After post-fixation and washing, the pellets were wrapped in agar (2\% solution), according to Pottu-Boumendil (1989). Agar blocks containing the cells were cut into small cubes $\left(1 \mathrm{~mm}^{3}\right)$. These cubes were then dehydrated in ethanol and propylene oxide series and further embedded in Araldite CY212 (TAAB) according to a routine procedure. Ultrathin sections $(50 \mathrm{~nm})$ were obtained on a Reichert-Jung ultramicrotome. Transmission electron microscopy observations were performed on an LEO 912 electron microscope, operated at $120 \mathrm{kV}$ with $\mathrm{a} \mathrm{LaB}_{6}$ source.

Determination of growth parameters. To determine the optimum temperature, $\mathrm{pH}$ and sea-salts concentration, cells were grown in Hungate tubes $(15 \mathrm{ml}$; Bellco) containing $6 \mathrm{ml}$ GYPS medium. Experiments were performed in thermostatic aluminium heating blocks (Bioblock) monitored with temperature probes placed in control tubes. To determine the effect of $\mathrm{pH}$ on the growth, the GYPS medium was modified with the following $10 \mathrm{mM}$ buffers (Sigma): for $\mathrm{pH} 3 \cdot 0,4 \cdot 0$ and $4 \cdot 5$, no buffer; for $\mathrm{pH} 5 \cdot 0,5 \cdot 5$ and $6 \cdot 0$, MES buffer; for $\mathrm{pH} 6.5$ and 7.0, PIPES buffer; for $\mathrm{pH} 7 \cdot 5$ and 8.0 , HEPES buffer; and for $\mathrm{pH} 8.5$ and 9.0, AMPSO [3-(1,1dimethyl-2-hydroxyethyl)-amino-2-hydroxypropanesulfonic acid] buffer. Sodium sulfide was added in the anaerobic chamber and, if necessary, the $\mathrm{pH}$ was adjusted with $0 \cdot 1 \mathrm{M}$ $\mathrm{HCl}$ or $0.1 \mathrm{M} \mathrm{NaOH}$. To determine the concentration of salts required for growth, the GYPS medium was prepared with different dilutions of sea salt. Cells were then incubated at the optimal temperature and $\mathrm{pH}$ for growth. The effects of temperature, $\mathrm{pH}$ and salinity were determined by measuring growth rates calculated using linear regression analysis from four to seven points along the logarithmic portions of the growth curves. All growth experiments were carried out in triplicate.

Determination of growth requirements. The ability of the new isolate to grow in the presence of different electron acceptors was investigated on GYPS medium in which elemental sulfur had been replaced with one of the following electron acceptors: L-cystine was tested at $50 \mathrm{mM}$, polysulfides (Blumentals et al., 1990) and ferric iron were tested at $10 \mathrm{mM}$, and thiosulfate, sulfate, sulfite, nitrate and nitrite were tested at $20 \mathrm{mM}$. Growth in the absence of elemental sulfur was also tested.

The ability of strain AM $1114^{\mathrm{T}}$ to use a single carbon source was investigated by adding one of the following organic compounds to the GYPS medium from which carbon sources had been omitted, and which was supplemented with $0.5 \mathrm{ml} \mathrm{l}^{-1}$ vitamin solution (Balch et al., 1979): $2 \mathrm{~g} \mathrm{l}^{-1}$ $\mathrm{NaHCO}_{3}, 10 \mathrm{ml} \mathrm{l}^{-1}$ trace-element solution (Balch et al., 1979) and $1 \mathrm{ml} \mathrm{l}^{-1}$ selenite/tungstate solution $\left(6 \mathrm{mg} \mathrm{l}^{-1}\right.$ $\mathrm{Na}_{2} \mathrm{SeO}_{3} .5 \mathrm{H}_{2} \mathrm{O} ; \quad 0.8 \mathrm{mg} \mathrm{l}^{-1} \quad \mathrm{Na}_{2} \mathrm{WO}_{4} .2 \mathrm{H}_{2} \mathrm{O} ; \quad 0.4 \mathrm{~g} \mathrm{l}^{-1}$ $\mathrm{NaOH}) . \mathrm{D}(+)$-Glucose and maltose were added at a final concentration of $0.5 \%(\mathrm{w} / \mathrm{v})$, while yeast extract and brain-heart infusion were tested at $0 \cdot 2 \%(\mathrm{w} / \mathrm{v})$. The ability of the strain to grow on pairs of amino acids (a wide range of amino acid pairs capable of being used via the Stickland reaction was tested) or on a mixture of 20 amino acids was also tested (for these experiments, the concentration of each amino acid was $0 \cdot 1 \mathrm{~g} \mathrm{l}^{-1}$ ). The following amino acids, which were rapidly consumed when the strain was cultivated on a mixture of 20 amino acids, were also tested singly at $0 \cdot 2 \mathrm{~g}^{-1}$ : L-serine, L-proline, L-asparagine, L-tryptophan, L-cysteine, L-isoleucine, L-leucine and L-phenylalanine. For the other carbon sources tested, a small amount of yeast extract
$(0.01 \% \mathrm{w} / \mathrm{v})$ was used in GYPS basal medium for culture induction. The following carbon sources were tested: gelatin, glycogen (from oyster), maltose, $\mathrm{D}(+)$-glucose, $\mathrm{D}(-)$-fructose, $\mathrm{D}(+)$-galactose, starch (soluble), dextran (from $L$. mesenteroides strain B-512, $M_{\mathrm{r}} 148000$; Sigma), cellulose, xylan (from oat spelts), chitin, $\mathrm{D}(+)$-cellobiose were tested to a final concentration of $0.5 \%(\mathrm{w} / \mathrm{v})$, while peptone, tryptone, formate and acetate were added at a final concentration of $0.2 \%(\mathrm{w} / \mathrm{v})$, and methanol at a final concentration of $0.5 \%(\mathrm{v} / \mathrm{v})$.

The ability of the strain to grow by homoacetogenesis was tested on a medium that had the following composition: sea salts, $30 \mathrm{~g} \mathrm{l}^{-1}$; PIPES buffer, $6.05 \mathrm{~g} \mathrm{l}^{-1} ; \mathrm{NH}_{4} \mathrm{Cl}, 1 \mathrm{~g} \mathrm{l}^{-1}$; $\mathrm{NaHCO}_{3}, 10 \mathrm{~g} \mathrm{l}^{-1}$; yeast extract, $0 \cdot 1 \mathrm{~g} \mathrm{l}^{-1}$; resazurin solution, $0 \cdot 1 \% \quad(\mathrm{v} / \mathrm{v}) ; \mathrm{KH}_{2} \mathrm{PO}_{4}, \quad 0.35 \mathrm{~g} \mathrm{l}^{-1} ; \mathrm{K}_{2} \mathrm{HPO}_{4}, \quad 0.35 \mathrm{~g} \mathrm{l}^{-1}$; $\mathrm{Na}_{2} \mathrm{~S} .9 \mathrm{H}_{2} \mathrm{O}, 0.5 \mathrm{~g} \mathrm{l}^{-1}$; selenite/tungstate solution, $1 \mathrm{ml} \mathrm{l}^{-1}$; trace-element solution (Balch et al., 1979), $10 \mathrm{ml}^{-1}$; vitamin solution (Balch et al., 1979), 0.5 $\mathrm{ml} \mathrm{l}^{-1}$. This experiment was performed under an $\mathrm{H}_{2} / \mathrm{CO}_{2}(80: 20 ; 200 \mathrm{kPa})$ gas phase.

All these tests were performed in duplicate, and positive cultures were transferred to confirm growth. Growth was determined by direct cell counting in a Thoma chamber (depth, $0.02 \mathrm{~mm}$ ) with a phase-contrast microscope.

Analytical techniques. All of the analyses of the metabolic end-products were carried out in triplicate. The amino acid, organic acid and aromatic acid metabolic end-products were analysed by means of HPLC (Alliance 2690; Waters) as described by Wery et al. (2001b). Proteins from the supernatant of the culture were precipitated with a solution of 5sulfosalicylic acid at $2 \%(\mathrm{w} / \mathrm{v})$. Amino acids were studied after derivatization [with an ethanol/water/triethylamine/ phenylisothiocyanate (7:1:1:1 by vol.) solution] under the conditions specified for the Waters Pico Tag method (WAT007360; Waters). Alcohols, glucose and linear organic acids were studied on an $\mathrm{H}^{+}$exclusion column (polyspher OAKC 1.51270; Merck) at $60{ }^{\circ} \mathrm{C}$ with a $18 \mathrm{mM} \mathrm{H}_{2} \mathrm{SO}_{4}$ elution $\left(0.35 \mathrm{ml} \mathrm{min}^{-1}\right)$ and with differential refractometer (refractometer 410; Waters) detection. For analysis of aromatic acids, the supernatant was eluted on an $\mathrm{H}^{+}$ exclusion column (column 28352; Chrompack) at $65^{\circ} \mathrm{C}$ by a $4.5 \mathrm{mM} \mathrm{H}_{2} \mathrm{SO}_{4}$ solution $\left(0.5 \mathrm{ml} \mathrm{min}^{-1}\right)$ and detected by absorbance at $210 \mathrm{~nm}$ (UV detector 486; Waters).

The gas composition was analysed using a AGILENT M200 gas microchromatograph equipped with two parallel analysis tracks [a molecular sieve-packed column (10 m) and a Poraplot U column $(8 \mathrm{~m})]$ and a thermal conductivity detector. Helium was used as the carrier gas.

$\mathbf{H}_{2} \mathbf{S}$ determination. $\mathrm{H}_{2} \mathrm{~S}$ formation was detected by the addition of $500 \mu \mathrm{l} 5 \mathrm{mM} \mathrm{CuSO} / 50 \mathrm{mM} \mathrm{HCl}$ to $0.2 \mathrm{ml}$ culture. A brown precipitate demonstrated the presence of $\mathrm{H}_{2} \mathrm{~S}$.

Susceptibility to antibiotics. Sensitivity to antibiotics was estimated by using $25,50,75$ and $100 \mu \mathrm{g} \mathrm{ml}^{-1}$ solutions of the following antibiotics: chloramphenicol, kanamycin, penicillin $G$, rifampicin, streptomycin and vancomycin. Antibiotic solutions were added to GYPS medium just before inoculation. When the antibiotic was diluted in ethanol (chloramphenicol) or DMSO (rifampicin), the same volume of solvent was added to the control cultures.

DNA extraction and purification. Genomic DNA was extracted as described by Wery et al. (2001a). The concentration and purity of the genomic DNA obtained were estimated by using a GenQuant II spectrophotometer 


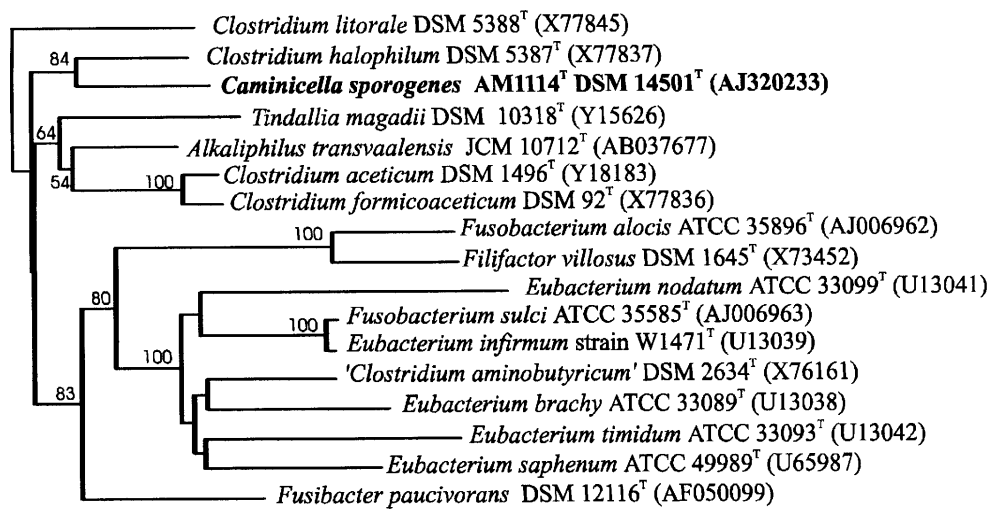

Fig. 1. Phylogenetic position of strain AM1114 ${ }^{\top}$ within the Clostridiales. The alignment was performed with 16S rDNA sequences of related species of Clostridium cluster XI. Clostridium litorale was used as an outgroup. Accession numbers are indicated in parentheses. The topology shown corresponds to an unrooted tree obtained using a neighbour-joining algorithm (Kimura corrections) established using PHYLO_WIN and manually refined using SEAVIEW. Bootstrap values are displayed on their relative branches. The scale bar indicates $6.0 \mathrm{nt}$ substitutions per $100 \mathrm{nt}$.

(Pharmacia) at 260, 280 and $320 \mathrm{~nm}$. The quality of the extraction was checked on a $0.8 \%(\mathrm{w} / \mathrm{v})$ agarose gel containing $0.5 \mu \mathrm{g}$ ethidium bromide $\mathrm{ml}^{-1}$.

DNA base content. The DNA was purified by caesium chloride gradient centrifugation (Sambrook et al., 1989), and its purity was checked spectrophotometrically. The $\mathrm{G}+\mathrm{C}$ content of the genomic DNA was determined from the melting point, according to the methods of Marmur et al. (1962), under the conditions reported by Raguénès et al. (1997). A calibration curve was constructed by using ultrapure DNA, as described by Wery et al. (2001a).

Amplification of the 16S rDNA. The 16S rDNA was selectively amplified from purified genomic DNA by a PCR with oligonucleotide primers designed to anneal to conserved positions in the $3^{\prime}$ and $5^{\prime}$ regions of the $16 \mathrm{~S}$ rRNA genes. The forward primer was SAdir (5'-AGAGTTTGATCATGGCTCAGA-3', corresponding to positions 8-28 in the Escherichia coli $16 \mathrm{~S}$ rRNA) and the reverse primer was S17rev (5'GTTACCTTGTTACGACTT-3', corresponding to positions 1493-1509). The initial denaturation step consisted of heating of the reaction mixture to $94{ }^{\circ} \mathrm{C}$ for $3 \mathrm{~min}$. This was followed by 30 cycles as follows: denaturation at $94{ }^{\circ} \mathrm{C}$ for $1 \mathrm{~min}$, annealing at $48^{\circ} \mathrm{C}$ for $1 \mathrm{~min} 30 \mathrm{~s}$, and extension at $72^{\circ} \mathrm{C}$ for $2 \mathrm{~min}$. A final extension step was carried out at $72{ }^{\circ} \mathrm{C}$ for 6 min. The PCR products were analysed on $0.8 \%$ $(\mathrm{w} / \mathrm{v})$ agarose TAE gels $(0.04 \mathrm{M}$ Tris-acetate, $0.001 \mathrm{M}$ EDTA), containing $0 \cdot 8 \mu \mathrm{g}$ ethidium bromide $\mathrm{ml}^{-1}$, and recorded with a Fluor-S multiImager (Bio-Rad).

$16 \mathrm{~S}$ rDNA sequence analysis. The $16 \mathrm{~S}$ rRNA gene was double-strand sequenced with the primers described by Raguénès et al. (1996). This work was done by Genome Express (Grenoble, France) with an automatic DNAanalysis system (Applied Biosystems); 1456 positions of the $16 \mathrm{~S}$ rDNA sequence were determined. The CLUSTAL w method with weighted residues was used to align the sequences of representative Clostridiales and to calculate similarity levels (Thompson et al., 1994). The 16S rDNA sequence alignment was refined manually by using the multiple sequence alignment editor SEAVIEW, and a phylogenetic reconstruction was produced using PHYLO_WIN (Galtier et al., 1996) with the following settings: neighbourjoining (Saitou et al., 1987) with the correction of Kimura (1980), maximum-parsimony (Lake, 1987) and maximumlikelihood (Felsenstein, 1981) methods. Bootstrap values were determined according to Felsenstein (1985). The strains and $16 \mathrm{~S}$ rDNA sequences used for phylogenetic analysis are given in Fig. 1.

\section{RESULTS AND DISCUSSION}

\section{Enrichment and isolation}

Growth of motile, rod-shaped micro-organisms was observed in enrichment cultures after $37 \mathrm{~h}$ incubation at $60{ }^{\circ} \mathrm{C}$. The enriched cultures were successfully subcultured, and one isolate was purified and referenced as strain AM1114 ${ }^{\mathrm{T}}\left(=\mathrm{DSM} 14501^{\mathrm{T}}=\mathrm{CIP}\right.$ $107141^{\mathrm{T}}$ ).

\section{Phylogenetic analysis}

The almost complete sequence (1456 bp) of the $16 \mathrm{~S}$ rDNA gene of strain AM1114 ${ }^{\mathrm{T}}$ was determined. The phylogenetic position of this organism was determined by comparing its $16 \mathrm{~S}$ rDNA sequence with those of representative ones from the 19 Clostridiales clusters (according to the scheme of Collins et al., 1994). For this phylogenetic reconstruction, Bacillus subtilis (GenBank/EMBL accession no. AB016721) was used as an outgroup. According to this first reconstruction, it was concluded that strain $\mathrm{AM} 1114^{\mathrm{T}}$ belonged to cluster XI of the lineage encompassing the genus Clostridium and related genera. A second phylogenetic tree was constructed, performed with species of cluster XI and one species of cluster XII (Caloranaerobacter azorensis DSM $13643^{\mathrm{T}}$, accession no. AJ272422; Wery et al., 2001b) as an outgroup. It showed that the sequence of AM1114 ${ }^{\mathrm{T}}$ was related to the Clostridium halophilum subcluster. Cluster XI is very large, and, consequently, the final phylogenetic reconstruction (Fig. 1) was performed only with closely related species among this cluster (with Clostridium litorale as an outgroup). The pairwise evolutionary distances based on 1441 unambiguous nucleotides were computed using the Kimura two-parameter model (Kimura, 1980), and a dendrogram was constructed from these distances using the neighbour-joining method. The species most closely related to AM1114 ${ }^{\mathrm{T}}$ was Clostridium halophilum (91\% 16S rDNA sequence similarity). It was followed by Clostridium formicoaceticum (90\%), Clostridium aceticum (90\%), Alkaliphilus transvaalensis $(90 \%)$ and Tindallia magadii $(90 \%)$. The positioning of strain AM $1114^{\mathrm{T}}$ was supported by the results of the three algorithms used: neighbour 

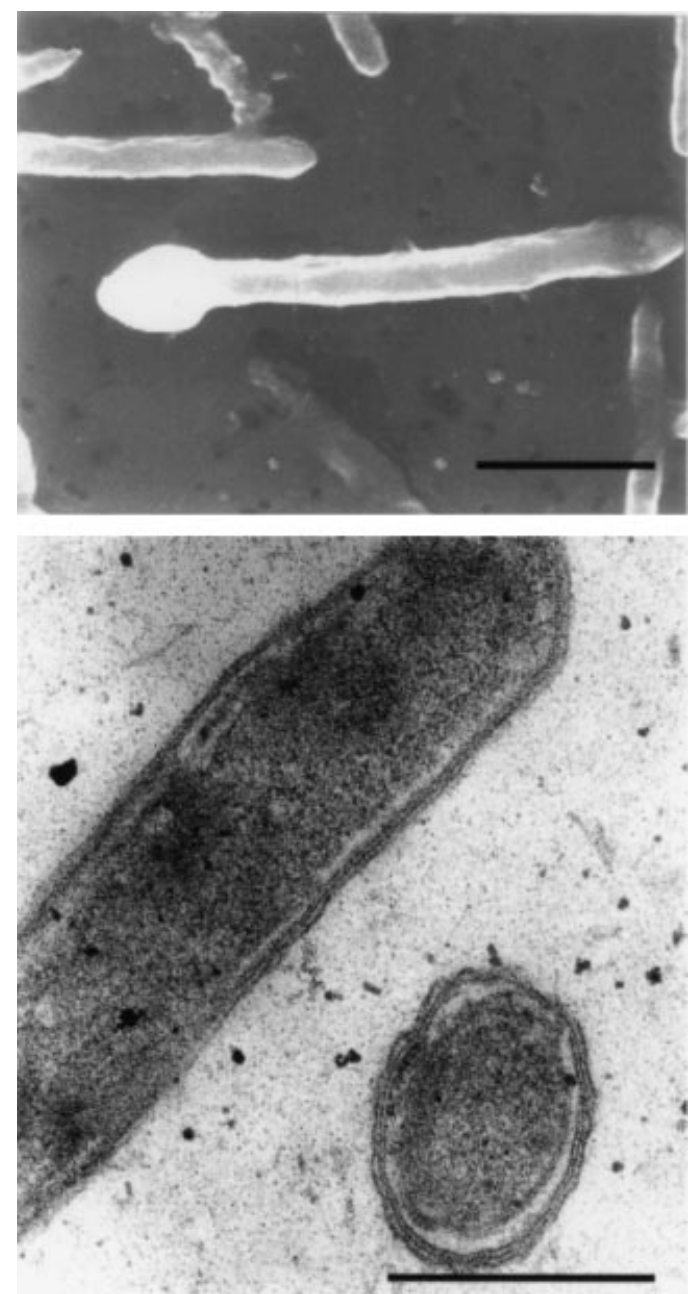

Fig. 2. (top) Scanning electron micrograph of strain $A M 1114^{\top}$ in the mid-exponential phase of growth, showing a sporulated cell. Bar, $2 \mu \mathrm{m}$. (bottom) Transmission electron micrograph of strain AM1114 ${ }^{\top}$ in the mid-exponential phase of growth, showing a cell wall with (from the inside to the outside) a cytoplasmic membrane, a thin peptidoglycan layer and an outer membrane - the characteristic cell wall ultrastructure of Gramnegative bacteria. Bar, $1 \mu \mathrm{m}$.

joining, maximum parsimony and maximum likelihood. The topology of the phylogenetic tree (Fig. 1) was also supported by the three algorithms used, except in the case of some branches (bootstraps $<50 \%$ ). To our knowledge, this is the first report of the isolation of a member of cluster XI (sensu Collins et al., 1994) within the lineage of the genus Clostridium and related genera from a deep-sea hydrothermal vent.

The genus Clostridium is intermixed with members of different genera, exhibiting-or not exhibiting-a combination of Clostridium-type properties. The taxonomic definition of the genus Clostridium, proposed by Prazmowski (Hippe et al., 1992), comprised only four (combined) criteria, i.e (1) an ability to form endospores; (2) an anaerobic type of energy metabolism;
(3) an inability to carry out the dissimilatory reduction of sulfate; and (4) a Gram-positive cell wall ultrastructure. Strain AM1114 ${ }^{\mathrm{T}}$ does not come close to meeting this definition.

\section{Morphological and physiological characteristics}

Scanning electron microscopy and phase-contrast microscopy indicated that cells of isolate AM $1114^{\mathrm{T}}$ were thin, straight to slightly curved rods approximately $0.5-0.7 \mu \mathrm{m}$ wide and 3-10 $\mu \mathrm{m}$ long (mean length, $6 \mu \mathrm{m}$ ) during the exponential phase of growth. They appeared as single cells (Fig. 2, top) or in pairs. Under unfavourable growth conditions and in the stationary phase of growth, cells elongated; occasionally, cells that were $17 \mu \mathrm{m}$ long were observed. The cells stained Gram-negative, and electron microscopy of thin sections of strain AM $1114^{\mathrm{T}}$ revealed the presence, in the cell wall, of a thin peptidoglycan layer characteristic of Gram-negative bacteria (Fig. 2, bottom). Moreover, the $\mathrm{KOH}$ reaction was positive, confirming the Gramnegative type of AM $1114^{\mathrm{T}}$ cells. In the late stationary phase of growth, cells formed an ovoid, refractile, terminal endospore (Fig. 2, top). Both non-sporulated and sporulated cells were motile by means of peritrichous flagella.

This isolate is not an exception among Gram-negative bacteria of the Firmicutes. In fact, the genus Clostridium sensu lato is polyphyletic and is related phylogenetically to several Gram-negative-staining taxa (for example Broda et al., 2000; Wery et al., 2001b).

Strain AM $1114^{\mathrm{T}}$ grew at $45-65^{\circ} \mathrm{C}$, the optimum being around $55-60^{\circ} \mathrm{C}$. No growth was observed at 40 or $70{ }^{\circ} \mathrm{C}$. The strain required $\mathrm{NaCl}$ for growth, and grew at sea-salt concentrations of between 20 and $60 \mathrm{~g} \mathrm{l}^{-1}$ (corresponding to $15-46 \mathrm{~g} \mathrm{NaCl}^{-1}$ ). The optimum sea-salt concentration was approximately $25-30 \mathrm{~g} \mathrm{l}^{-1}$ (corresponding to 19-23 $\mathrm{g} \mathrm{NaCl}^{-1}$ ). Growth occurred at $\mathrm{pH} 4 \cdot 5-8 \cdot 0$, the optimum $\mathrm{pH}$ being around $7 \cdot 5-8 \cdot 0$.

\section{Metabolic properties}

Strain $\mathrm{AM} 1114^{\mathrm{T}}$ is an anaerobic, obligately heterotrophic bacterium unable to grow by homoacetogenesis. The isolate was able to grow on complex proteinaceous substrates and carbohydrates. Very active growth was observed on yeast extract as the sole energy and carbon source. Although weak growth occurred on a mixture of 20 amino acids, the strain was unable to grow on amino acid pairs via the Stickland reaction.

On the other hand, the other substrates tested as sole carbon sources did not allow growth. In the presence of $0.01 \%(\mathrm{w} / \mathrm{v})$ yeast extract, growth on brain-heart infusion, $\mathrm{D}(+)$-glucose and maltose was supported. Poor growth was observed on peptone and on $\mathrm{D}(+)$ galactose (in the presence of $0.01 \%, \mathrm{w} / \mathrm{v}$, yeast extract). None of the other organic acids, alcohols or 
carbohydrates tested in combination with $0.01 \%(\mathrm{w} / \mathrm{v})$ yeast extract supported growth. No requirement for an external electron acceptor was observed. Despite the fact that elemental sulfur, L-cystine and thiosulfate did not clearly enhance growth, they were reduced to hydrogen sulfide. Conversely, no growth was observed in the presence of nitrites, sulfites and polysulfides. Ferric iron, sulfates and nitrates did not enhance growth. These data suggest that the isolated strain is an obligately fermentative bacterium.

The lineage that encompasses the genus Clostridium and related genera is metabolically heterogeneous, containing a large proportion of fermentative microorganisms (Hippe et al., 1992; Rainey et al., 1993; Takai et al., 2001). The isolate does not stand out from the majority. It is a strictly chemoorganoheterotrophic bacterium able to ferment complex proteinaceous substrates and carbohydrates.

Under optimal growth conditions (with yeast extract as a carbon and energy source, sulfur as an external electron acceptor, and at optimal temperature, $\mathrm{pH}$ and salinity), the final concentration in vials was around $8 \times 10^{8}$ cells $\mathrm{ml}^{-1}$, and the generation time was approximately $45 \mathrm{~min}$.

During fermentation on GYPS medium, strong growth was observed. Notably, a high consumption of glucose (i.e. $2 \cdot 3 \mathrm{~g} \mathrm{l}^{-1}$ ) concomitant with high levels of production of hydrogen, carbon dioxide, acetate $(7.50 \mathrm{mM})$, butyric acid $(0.82 \mathrm{mM})$ and ethanol $(10.7 \mathrm{mM})$ was observed (the values given above and below were performed at the end of the exponential phase of growth). Weak production of butanol was also observed $(0 \cdot 1 \mathrm{mM})$. Moreover, $0.05 \mathrm{mM}$ succinate and the small amounts of free amino acids (aspartate, glutamate, asparagine, serine, histidine, methionine, cysteine, isoleucine, leucine, phenylalanine, tryptophan and lysine) available in the medium were consumed. At the same time, formate $(3 \mathrm{mM})$ and $\mathrm{L}-$ alanine $(0.08 \mathrm{mM})$ were produced. Weak increases in the hydroxyphenylacetate, phenylacetate, propionate, isobutyrate, isovalerate and pyruvate concentrations in the medium were also measured, together with small increases in the glycine and proline concentrations (probably obtained by degradation of the yeast-extract proteins). When the strain was cultivated in a medium containing a mixture of 20 amino acids (each at a concentration of $0 \cdot 1 \mathrm{~g}^{-1}$ ), weak growth was observed, and serine, proline, asparagine, tryptophan, cysteine, isoleucine, leucine and phenylalanine were partially consumed.

Thus, the results of the analysis of the metabolic endproducts clearly indicated that the strain is a heterofermentative bacterium that degrades glucose via the butyric acid fermentation pathway. This fermentation pathway is widely distributed among the genus Clostridium and related genera. Catabolic end-products of glucose fermentation included the butyrate produced via the butyrate pathway, and acetate, ethanol, hydrogen and carbon dioxide produced via secondary parallel pathways. However, acetone and 2-propanol were not produced, indicating that the acetone/2propanol parallel pathway was not activated. The inhibition of this pathway could be due to the high concentrations of carbon dioxide produced in the medium, as has been described previously for many clostridia.

On the other hand, a significant amount of L-alanine was excreted into the medium during glucose fermentation. This phenomenon has been previously reported for some thermophilic micro-organisms belonging to the Thermotogales (Ravot et al., 1996), the Thermococcales (Kengen et al., 1994; Kobayashi et al., 1995) and the Clostridiales (Fardeau et al., 2001). It has been correlated, in most cases, with an increase in the $\mathrm{H}_{2}$ partial pressure. The production of L-alanine could be a way of avoiding the possible 'toxic' or inhibiting effect of $\mathrm{H}_{2}$ excesses, i.e. by attaching them to a carbon structure that would be secreted. Under cultivation in the presence of $\mathrm{S}^{0}$, an additional mechanism for preventing this inhibition could be the production of $\mathrm{H}_{2} \mathrm{~S}$, as has been observed in this work.

\section{Susceptibility to antibiotics}

Growth of isolate AM1114 ${ }^{\mathrm{T}}$ was inhibited by vancomycin, chloramphenicol, rifampicin and penicillin $\mathrm{G}$ at the lowest concentrations tested $\left(25 \mu \mathrm{g} \mathrm{ml}^{-1}\right)$, and by streptomycin at $50 \mu \mathrm{g} \mathrm{ml}^{-1}$. The strain was resistant to $100 \mu \mathrm{g}$ kanamycin $\mathrm{ml}^{-1}$.

\section{DNA base composition}

The $\mathrm{G}+\mathrm{C}$ content of the genomic DNA of strain AM $1114^{\mathrm{T}}$ was $24 \cdot 2 \pm 1 \mathrm{~mol} \%$.

\section{Taxonomic position of the novel isolate}

The closest phylogenetic relatives of strain AM1114 were Clostridium halophilum (Fendrich et al., 1990) (91\% similarity) followed by Clostridium formicoaceticum (Andreesen et al., 1970), Clostridium aceticum (Braun et al., 1981), Alkaliphilus transvaalensis (Takai et al., 2001) and T. magadii (Kevbrin et al., 1998) (mean similarity of $90 \%$ ). In addition to the phylogenetic distances $(9-10 \%)$, strain AM1114 ${ }^{\mathrm{T}}$ exhibited significant genotypic and phenotypic differences from its nearest phylogenetic neighbours: (1) cells of strain AM $1114^{\mathrm{T}}$ stain Gram-negative, whereas cells of Clostridium halophilum, T. magadii and Alkalphilus transvaalensis stain Gram-positive; (2) Clostridium aceticum and Clostridium formicoaceticum are acetogens capable of chemolithoautotrophic and aromatic-dependent growth; (3) T. magadii and Alkalphilus transvaalensis are true alkaliphilic micro-organisms; (4) Clostridium halophilum is halophilic; (5) the temperature ranges for growth are very different: the new isolate is thermophilic, and its closest phylogenetic relatives are mesophiles; (6) the $\mathrm{G}+\mathrm{C}$ content of the genomic DNA of the isolate is $24.2 \mathrm{~mol} \%$, while those of the closest relatives range from 26.9 to $37.6 \mathrm{~mol} \%$ (for 
Clostridium halophilum and T. magadii, respectively). In addition, T. magadii was an asporogenous bacterium.

On the basis of the overall 16S rDNA dissimilarity value between strain AM1114 ${ }^{\mathrm{T}}$ and the closest described relatives $(9-10 \%)$ as well as the major phenotypic and genotypic differences, we propose that AM1114 ${ }^{\mathrm{T}}$ should be assigned to a new genus within cluster XI of the Clostridium subphylum. Because of its origin in a hydrothermal vent, we name this genus Caminicella, and, because of its ability to form spores, we name the new species Caminicella sporogenes.

\section{Description of Caminicella gen. nov.}

Caminicella (Ca.mi'ni.cel'la. L. gen. n. camini of a chimney, relating to the hydrothermal chimney origin; L. fem. n. cella cell; N.L. fem. n. caminicella cell from a hydrothermal chimney).

Cells are rod-shaped, motile, and stain Gram-negative. Spore-forming thermophile, adapted to the $\mathrm{pH}$ and salinity of the ocean. Anaerobic and heterotrophic; able to ferment proteinaceous substrates and carbohydrates. 16S rDNA sequence comparisons locate the Caminicella genus in the domain Bacteria, within cluster XI of the lineage encompassing the genus Clostridium and related genera (Collins et al., 1994).

\section{Description of Caminicella sporogenes sp. nov.}

Caminicella sporogenes (spo.rog.en'es. M.L. n. spora a spore; Gr. v. gennaio produce; M.L. part. adj. sporogenes spore-producing).

Cells are rod-shaped $(3-10 \mu \mathrm{m}$ long $\times 0 \cdot 5-0 \cdot 7 \mu \mathrm{m}$ wide), motile by means of peritrichous flagella, and exhibit a Gram-negative cell wall ultrastructure. Sporulation is observed in the late stationary phase of growth. Growth occurs at $45-65^{\circ} \mathrm{C}$ (optimum, 55$60{ }^{\circ} \mathrm{C}$ ), at $\mathrm{pH} 4 \cdot 5-8.0$ (optimum, $\mathrm{pH} 7 \cdot 5-8 \cdot 0$ ), and at sea salt concentrations of 20-60 g $1^{-1}$ (optimum, 25$30 \mathrm{~g}$ sea salt $1^{-1}$ ). The optimal doubling time is around $45 \mathrm{~min}$; the maximum cell yield is $8 \times 10^{8}$ cells $\mathrm{ml}^{-1}$ in vials. Anaerobic. Able to ferment yeast extract, brainheart infusion, $\mathrm{D}(+)$-glucose, maltose, and, to a much lesser extent, peptone, galactose and a mixture of 20 amino acids. The main fermentation products on GYPS medium are $\mathrm{H}_{2}, \mathrm{CO}_{2}$, butyrate, ethanol, acetate, formate and L-alanine. The $\mathrm{G}+\mathrm{C}$ content of the genomic DNA is $24.2 \pm 1 \mathrm{~mol} \%$. The $16 \mathrm{~S}$ rDNA similarity to Clostridium halophilum is $91 \%$. The GenBank/EMBL accession number for the 16S rDNA sequence is AJ320233. The type strain, AM1114 $\left(=\right.$ CIP $\left.107141^{\mathrm{T}}=\mathrm{DSM} 14501^{\mathrm{T}}\right)$, was isolated from young entire Alvinella pompejana tubes attached to small fragments of chimney rocks that were collected from the hydrothermal site Elsa (HOT3) in the EastPacific Rise $\left(103^{\circ} 56^{\prime} 326 \mathrm{~W}, 12^{\circ} 48^{\prime} 200 \mathrm{~N}\right)$.

\section{ACKNOWLEDGEMENTS}

We thank the chief scientists of the French oceanographical cruise AMISTAD ('Advanced Microbiological Studies of Thermophiles: Adaptations and Diversity', 1999), C. Jeanthon, the Captain and the crew of NO Atalante, and the DSV Nautile pilots and support crew. This work was supported by the Région Bretagne and the French Dorsales Programme. Electron microscopy was performed at the 'service de Microscopie Electronique', IFR de biologie integrative, CNRS/Paris VI.

\section{REFERENCES}

Adamse, A. D. (1980). New isolation of Clostridium aceticum (Wieringa). Antonie Leeuwenhoek 46, 523-531.

Andreesen, J. R., Gottschalk, G. \& Schlegel, H. G. (1970). Clostridium formicoaceticum nov. spec. isolation, description and distinction from C. aceticum and C. thermoaceticum. Arch Microbiol 72, 154-174.

Balch, W. E., Fox, G. E., Magrum, L. J., Woese, C. R. \& Wolfe, R. S. (1979). Methanogens: reevaluation of a unique biological group. Microbiol Rev 43, 260-296.

Baross, J. A. (1995). Isolation, growth and maintenance of hyperthermophiles. In Archaea: a Laboratory Manual. Thermophiles, pp. 15-23. Edited by F. T. Robb, A. R. Place, K. R. Sowers, H. J. Schreier, S. DasSarma \& E. M. Fleischmann. Cold Spring Harbor, NY: Cold Spring Harbor Laboratory

Blumentals, I. I., Itoh, M., Olson, G. J. \& Kelly, R. M. (1990). Role of polysulfides in reduction of elemental sulfur by the hyperthermophilic archaebacterium Pyrococcus furiosus. Appl Environ Microbiol 56, 1255-1262.

Braun, M., Mayer, F. \& Gottschalk, G. (1981). Clostridium aceticum (Wieringa), a microorganism producing acetic acid from molecular hydrogen and carbon dioxide. Arch Microbiol 128, 288-293.

Broda, D. M., Saul, D. J., Bell, R. G. \& Musgrave, D. R. (2000). Clostridium algidixylanolyticum sp. nov., a psychrotolerant, xylandegrading, spore-forming bacterium. Int J Syst Evol Microbiol 50, 623-631.

Buck, J. D. (1982). Nonstaining (KOH) method for determination of Gram reactions of marine bacteria. Appl Environ Microbiol 44, 992-993.

Cato, E. P., George, W. L. \& Finegold, S. M. (1986). Genus Clostridium Prazmowski 1880, 23 ${ }^{\mathrm{AL}}$. In Bergey's Manual of Systematic Bacteriology, vol. 2, pp. 1141-1200. Edited by P. H. A. Sneath, N. S. Mair, M. E. Sharpe \& J. G. Holt. Baltimore: Williams \& Wilkins.

Collins, M. D., Lawson, P. A., Willems, A., Cordoba, J. J., Fernandez-Garayzabal, J., Garcia, P., Cai, J., Hippe, H. \& Farrow, J. A. E. (1994). The phylogeny of the genus Clostridium: proposal of five new genera and eleven new species combinations. Int $J$ Syst Bacteriol 44, 812-826.

Fardeau, M. L., Ollivier, B., Garcia, J. L. \& Patel, B. K. C. (2001). Transfer of Thermobacteroides leptospartum and Clostridium thermolacticum as Clostridium stercorarium subsp. leptospartum subsp. nov., comb. nov. and C. stercorarium subsp. thermolacticum subsp. nov., comb. nov. Int J Syst Evol Microbiol 51, 1127-1131.

Felsenstein, J. (1981). Evolutionary trees from DNA sequences: a maximum likelihood approach. $J$ Mol Evol 17, 368-376.

Felsenstein, J. (1985). Confidence limits on phylogenies: an approach using the bootstrap. Evolution 30, 783-791.

Fendrich, C., Hippe, H. \& Gottschalk, G. (1990). Clostridium halophilium sp. nov. and C. litorale sp. nov., an obligate halophilic and a marine species degrading betaine in the Stickland reaction. Arch Microbiol 154, 127-132.

Galtier, N., Gouy, M. \& Gautier, C. (1996). SEAVIEW and PHYLO_WIN: two graphic tools for sequence alignment and molecular phylogeny. CABIOS 12, 543-548. 
Hippe, H., Andreesen, J. R. \& Gottschalk, G. (1992). The genus Clostridium - nonmedical. In The Prokaryotes, vol. 2, pp. 1800-1866. Edited by A. Balows, H. G. Trüper, M. Dworkin, W. Harder \& K. H. Schleifer. New York: Springer.

Jalava, J. \& Eerola, E. (1999). Phylogenetic analysis of Fusobacterium alocis and Fusobacterium sulci based on 16S rRNA gene sequences: proposal of Filifactor alocis (Cato, Moore and Moore) comb. nov. and Eubacterium sulci (Cato, Moore and Moore) comb. nov. Int J Syst Bacteriol 46, 1375-1379.

Jeanthon, C. (2000). Molecular ecology of hydrothermal vent microbial communities. Antonie Leeuwenhoek 77, 117-133.

Kengen, S. W. M. \& Stams, A. J. M. (1994). Formation of L-alanine as a reduced end product in carbohydrate fermentation by the hyperthermophilic archaeon Pyrococcus furiosus. Arch Microbiol 161, $168-175$.

Kevbrin, V. V., Zhilina, T. N., Rainey, F. A. \& Zavarzin, G. A. (1998). Tindallia magadii gen. nov., sp. nov.: an alkaliphilic anaerobic ammonifier from soda lake deposits. Curr Microbiol 37, 94-100.

Kimura, M. (1980). A simple method for estimating evolutionary rates of base substitutions through comparative studies of nucleotide sequence. J Mol Evol 16, 111-120.

Kobayashi, T., Higuchi, S., Kimura, K., Kudo, T. \& Horikoshi, K. (1995). Properties of glutamate dehydrogenase and its involvement in alanine production in a hyperthermophilic archaeon, Thermococcus profundus. J Biochem 118, 587-592.

Lake, J. A. (1987). A rate-independent technique for analysis of nucleic acid sequences: evolutionary parsimony. Mol Biol Evol 4, 167-191.

Li, Y., Mandelco, L. \& Wiegel, J. (1993). Isolation and characterization of a moderately thermophilic anaerobic alkaliphile, Clostridium paradoxum sp. nov. Int J Syst Bacteriol 43, 450-460.

Li, Y., Engle, M., Weiss, N., Mandelco, L. \& Wiegel, J. (1994). Clostridium thermoalcaliphilum sp. nov., an anaerobic and thermotolerant facultative alkaliphile. Int J Syst Bacteriol 44, 111-118.

Longnecker, K. \& Reysenbach, A. L. (2001). Expansion of the geographic distribution of a novel lineage of E-Proteobacteria to a hydrothermal vent site on the Southern East Pacific Rise. FEMS Microbiol Ecol 35, 287-293.

Lux, M. F. \& Drake, H. L. (1992). Re-examination of the metabolic potentials of the acetogens Clostridium aceticum and Clostridium formicoaceticum: chemolithoautotrophic and aromatic-dependent growth. FEMS Microbiol Lett 74, 49-56.

Marmur, J. \& Doty, P. (1962). Determination of the base composition of deoxyribonucleic acid from its thermal denaturation temperature. J Mol Biol 5, 109-118.

Moyer, C. L., Dobbs, F. C. \& Karl, D. M. (1995). Phylogenetic diversity of the bacterial community from a microbial mat at an active, hydrothermal vent system, Loihi Seamount, Hawaii. Appl Environ Microbiol 61, 1555-1562.

Moyer, C. L., Tiedje, J. M., Dobbs, F. C. \& Karl, D. M. (1998). Diversity of deep-sea hydrothermal vent Archaea from Loihi Seamount, Hawaii. Deep-Sea Res Part II 45, 303-317.

Polz, M. F. \& Cavanaugh, C. M. (1995). Dominance of one bacterial phylotype at a Mid-Atlantic Ridge hydrothermal vent site. Proc Natl Acad Sci U S A 92, 7232-7236.

Pottu-Boumendil, J. (1989). Principes et méthodes de préparation. In Techniques en Microscopie Électronique, pp. 51-57. Paris: INSERM Editions.

Powers, E. M. (1995). Efficacy of the Ryu nonstaining KOH technique for rapidly determining Gram reactions of food-borne and waterborne bacteria and yeasts. Appl Environ Microbiol 61, 3756-3758.
Raguénès, G., Pignet, P., Gauthier, G., Peres, A., Christen, R., Rougeaux, H., Barbier, G. \& Guezennec, J. (1996). Description of a new polymer-secreting bacterium from a deep-sea hydrothermal vent, Alteromonas macleodii subsp. fijiensis, and preliminary characterization of the polymer. Appl Environ Microbiol 62, 67-73.

Raguénès, G., Christen, R., Guézennec, J., Pignet, P. \& Barbier, G. (1997). Vibrio diabolicus sp. nov., a new polysaccharide-secreting organism isolated from a deep-sea hydrothermal vent polychaete annelid, Alvinella pompejana. Int J Syst Bacteriol 47, 989-995.

Rainey, F. A. \& Stackebrandt, E. (1993). 16S rDNA analysis reveals the phylogenetic diversity among the polysaccharolytic clostridia. FEMS Micobiol Lett 113, 125-128.

Rainey, F. A., Ward, N. L., Morgan, H. W., Toalster, R. \& Stackebrandt, E. (1993). Phylogenetic analysis of anaerobic thermophilic bacteria: aid for their reclassification. J Bacteriol 175, 4772-4779.

Ravot, G., Ollivier, B., Fardeau, M.-L., Patel, B. K. C., Andrews, K. T., Magot, M. \& Garcia, J.-L. (1996). L-alanine production from glucose fermentation by hyperthermophilic members of the domains Bacteria and Archaea: a remnant of an ancestral metabolism? Appl Environ Microbiol 62, 2657-2659.

Ravot, G., Magot, M., Fardeau, M. L., Patel, B. K. C., Thomas, P., Garcia, J. L. \& Ollivier, B. (1999). Fusibacter paucivorans gen. nov., an anaerobic, thiosulfate-reducing bacterium from an oil-producing well. Int J Syst Bacteriol 46, 1141-1147.

Reysenbach, A. L., Longnecker, K. \& Kirshtein, J. (2000). Novel bacterial and archaeal lineages from an in situ growth chamber deployed at a Mid-Atlantic Ridge hydrothermal vent. Appl Environ Microbiol 66, 3798-3806.

Ryu, E. (1940). A simple method of differentiation between Grampositive and Gram-negative organisms without staining. Kitasato Arch Exp Med 17, 58-63.

Saitou, M. \& Nei, M. (1987). The neighbour-joining method: a new method for reconstructing phylogenetic trees. Mol Biol Evol 4, 406-425.

Sambrook, J., Fritch, E. F. \& Maniatis, T. (1989). Molecular Cloning: a Laboratory Manual, 2nd edn. Cold Spring Harbor, NY : Cold Spring Harbor Laboratory.

Stackebrandt, E., Kramer, I., Swiderski, J. \& Hippe, H. (1999). Phylogenetic basis for a taxonomic dissection of the genus Clostridium. FEMS Immunol Med Microbiol 24, 253-258.

Takai, K. \& Horikoshi, K. (1999). Genetic diversity of Archaea in deepsea hydrothermal vent environments. Genetics 152, 1285-1297.

Takai, K., Moser, D. P., Onstott, T. C., Spoelstra, N., Pfiffner, S. M., Dohnalkova, A. \& Fredrickson, J. K. (2001). Alkaliphilus transvaalensis gen. nov., sp. nov., an extremely alkaliphilic bacterium isolated from a deep South African gold mine. Int J Syst Evol Microbiol 51, 1245-1256.

Thompson, J. D., Higgins, D. G. \& Gibson, T. J. (1994). CLUSTAL W: improving the sensitivity of progressive multiple sequence alignment through sequence weighting, position-specific gap penalties and weight matrix choice. Nucleic Acids Res 22, 4673-4680.

Wery, N., Lesongeur, F., Pignet, P., Derennes, V., CambonBonavita, M. A., Godfroy, A. \& Barbier, G. (2001a). Marinitoga camini gen. nov., sp. nov., a rod-shaped bacterium belonging to the order Thermotogales, isolated from a deep-sea hydrothermal vent. Int $J$ Syst Evol 51, 495-504.

Wery, N., Moricet, J. M., Cueff, V., Jean, J., Pignet, P., Lesongeur, F., Cambon-Bonavita, M. A. \& Barbier, G. (2001b). Caloranaerobacter azorensis gen. nov., sp. nov., an anaerobic thermophilic bacterium, isolated from a deep-sea hydrothermal vent. Int J Syst Evol Microbiol 51, 1789-1796. 